\title{
In Vitro Toxicity Test of Strichnos johnsonnii (Loganiaceae) on a Strain of Staphylococcus aureus
}

\author{
Cecile Okalla Ebongue ${ }^{1,2, *}$, Fanny Aimee Essombe Malolo ${ }^{3}$, François Eya Ane Meva ${ }^{3}$, \\ Lidwine $\mathrm{Ngah}^{3}$, Jean Claude Ndom ${ }^{4}$, Emmanuel Mpondo Mpondo \\ ${ }^{1}$ Clinical biology Laboratory, General Hospital of Douala, Douala, Cameroon \\ ${ }^{2}$ Department of Biological Sciences, Faculty of Medicine and Pharmaceutical Sciences, University of Douala, Douala, Cameroon \\ ${ }^{3}$ Department of Pharmaceutical Sciences, Faculty of Medicine and Pharmaceutical Sciences, University of Douala, Douala, Cameroon \\ ${ }^{4}$ Department of Biological Sciences, Faculty of Sciences, University of Douala, Douala, Cameroon
}

\section{Email address:}

cecileokalla@yahoo.fr (C. O. Ebongue)

\section{To cite this article:}

Cecile Okalla Ebongue, Fanny Aimee Essombe Malolo, François Eya Ane Meva, Lidwine NGAH, Jean Claude Ndom, Emmanuel Mpondo Mpondo. In Vitro Toxicity Test of Strichnos johnsonnii (Loganiaceae) on a Strain of Staphylococcus aureus. Journal of Diseases and Medicinal Plants. Vol. 1, No. 3, 2015, pp. 48-52. doi: 10.11648/j.jdmp.20150103.12

\begin{abstract}
The aim of this study was to test the in vitro toxicity of an extract of Strychnos johnsonii (Loganiaceae) on a strain of Staphylococcus aureus. The tests were performed in the bacteriology unit of the Douala General Hospital biology laboratory, dealing with an extract from the bark of stem of Strychnos johnsonii (Loganiaceae) harvested at Etome village, South West Cameroon and authenticated by a botanist. The plant extract was obtained by maceration in $300 \mathrm{~mL}$ of ethanol for 120 hours. The filtrate obtained was evaporated under vacuum, at $50^{\circ} \mathrm{C}, 250$ mbar of pressure and at a speed of 125 rounds per minute. The residual solvent was eliminated in an incubator at $37^{\circ} \mathrm{C}$ for one week to give dry extract. Selected bacterial strain came from pus collected from an in-patient. By its biochemical and enzymatic characters, this strain showed $90.9 \%$ homology with the Staphylococcus aureus ATCC 29213-reference strain. No bacterial growth were observed on Mannitol Salt, EMB and Sabouraud-Chloramphenicol agar plates after 48 hours of incubation, evidence that the extract contained no germs before the test. The number of initial colonies for the time t 0 averaged 225. The point of intersection between the inhibition curve and the $\mathrm{x}$-axis as the MIC corresponds to $0,04 \mathrm{~g} / \mathrm{mL}$. The smallest concentration of the extract for which the growth of Staphylococcus aureus is zero on the Mannitol salt agar was $0.04 \mathrm{~g} / \mathrm{mL}$. Therefore, the MIC amounts to MBC. The results obtained showed a bactericidal effect, which could be, attributed to the presence of indole alkaloids in the plant.
\end{abstract}

Keywords: Strychnos johnsonii, In Vitro Toxicity, Staphylococcus aureus

\section{Introduction}

Worldwide, the use of traditional medicine is widespread and his health and economic importance is increasing. It is estimated that in Africa, $80 \%$ of the populations are using medicinal plants to heal, often because of the lack of access to medicines prescribed by modern medicine but also because these plants are effective [1]. Ethno botany and the Ethno pharmacology are working to identify active deemed plants and that it belongs to the modern research to specify properties and validate uses. Research of new pharmacologic agents undertaken within the plant biodiversity through the screening of natural sources, has enabled the discovery of a large number of drugs that play a major role in the treatment of many human diseases; As examples, the quinine from Cinchona ledgeriana, and artemisinin extracted from
Artemisia annua (antimalarial), vinblastine extracted from Catharanthus roseus (anti-cancer) [1,2]. Some of these plants are present in Cameroon, a Central African country located in the Gulf of Guinea, in which most of the southern part consists of forest.

Among Cameroonian medicinal plants, the species Strychnos johnsonii has interesting pharmacological potential molecules. As revealed in some studies including in central Africa, the Strychnos genus is rich in alkaloids, molecules with cytostatic, anti parasitic, antibacterial properties [3-7]. It is part of the large family of Loganiaceae, which has 394 species identified, with around 300 distributed in African's savannas and forests $[8,9]$.

Wood, stem and root bark are the parts of the plant used in 
decoction, maceration or infusion for their purgatives, emetic, anti parasitic, antipyretic and analgesics effects [9,10]. In Cameroon, Strychnos johnsonii is used as antipyretic. Fever is the major symptom of pathology of viral, parasitic and / or bacterial origin; a decrease in the bacterial load due to the effect of Strychnos johnsonii extract may justify its use as a febrifuge [11]. Our study was designed to test the in vitro toxicity of an extract of Strychnos johnsonii on a strain of Staphylococcus aureus.

\section{Materials and Methods}

We conducted a study of in vitro toxicity in the bacteriology unit of the Douala General Hospital laboratory, using an extract from the bark of the stem of Strychnos johnsonii (Loganiaceae) harvested at Etome village, South West Cameroon and authenticated by a botanist.

\subsection{Preparation of Plant Extract}

The plant extract was obtained by maceration of a quantity equivalent to $100 \mathrm{~g}$ of powdered bark of stem in $300 \mathrm{~mL}$ of ethanol for 120 hours.

The filtrate obtained was evaporated under vacuum, at $50^{\circ} \mathrm{C}, 250$ mbar of pressure and at a speed of 125 revolutions per minute in a rotative evaporator (rotavapor HEIDOLPH $\mathrm{G1}^{\mathrm{TM}}$ ) associated with a water bath and a vacuum pump
HEIDOLPH ${ }^{\mathrm{TM}}$. The residual solvent was eliminated in an incubator at $37^{\circ} \mathrm{C}$ for one week to give $1.675 \mathrm{~g}$ of dry extract.

\subsection{Control of Sterility of the Extract}

This extract has undergone scrutiny of sterility by seeding $75 \mathrm{mg}$, diluted in the Müller Hinton broth and incubated 48 hours at $37^{\circ} \mathrm{C}$ on Mannitol salt and Eosin Methylene Blue (EMB) agar plates, and at $30^{\circ} \mathrm{C}$ on SabouraudChloramphenicol agar.

\subsection{Selection of the Bacterial Strain}

Selected bacterial strain came from pus collected from a hospitalize patient. It had been identified by automatic colorimetric reading of an ID32 STAPH $^{\circledR}$ gallery on Mini $\mathrm{API}^{\mathrm{TM}}$ (BIOMÉRIEUX SA France) after plating onto Mannitol salt agar and incubation at $37^{\circ} \mathrm{C}$ for 24 hours. As a result of its biochemical and enzymatic characteristics, this strain showed $90.9 \%$ homology with the Staphylococcus aureus ATCC 29213-reference strain.

We then performed a susceptibility test of this strain using the ATB STAPH ${ }^{\circledR}$ gallery with automatic turbidimetric reading on Mini $\mathrm{API}^{\mathrm{TM}}$. Biochemical profile and the results of the susceptibility tests are presented in tables 1 and 2 respectively.

Table 1. biochemical profile of selected Staphylococcus aureus stream.

\begin{tabular}{llllllllllllll}
\hline Character & URE & NIT & ADH & VP & ODC & $\beta$ GAL & ESC & ArgA & GLU & PAL & FRU & PyrA & MNE \\
Result & + & + & - & + & - & - & - & - & + & + & + & - & + \\
Character & TUR & MAN & ARA & RAF & $\beta$ GUR & NOVO & MAL & SAC & LAC & NAG & TRE & \\
Result & + & + & - & - & - & - & + & + & - & + & + & & + \\
\hline
\end{tabular}

URE: urea, NIT: nitrate, ADH: Arginine dehydrogenase, VP: Voges Proscaert, ODC: Ornithine decarboxylase, $\beta$ GAL: $\beta$-Galactosidase, ESC: Esculine, ArgA: Arginine, GLU: Glucose, PAL: Naphtylphosphate, FRU: Fructose, PyrA: pyroglutamic $\beta$ Acid, MNE: Mannose, TUR: Turanose, MAN: Mannitol, ARA: Arabinose, RAF: Raffinose, $\beta$ GUR: $\beta$-glucuronide, NOVO: Novobiocine, MAL: Maltose, SAC: Saccharose, LAC: Lactose, NAG: N - Acetyl - glucosamine, TRE: Trehalose

Table 2. Susceptibility profile of selected Staphylococcus aureus stream.

\begin{tabular}{llllllllllll}
\hline ATB & PEN & OXA & KAN & TOB & GEN & ERY & LIN & CLI & PRI & QDA & \\
Result & S & S & S & S & S & R & S & S & S & S \\
ATB & FUC & FOS & FUR & TSU & VAN & TEC & TET & MIN & LVX & OFL & LNZ \\
Result & S & S & S & S & S & S & S & S & S & S & S \\
\hline
\end{tabular}

PEN: Penicillin G, OXA: Oxacilline, KAN: Kanamycin, TOB: Tobramycin, GEN: Gentamycin, ERY: Erythromycin, LIN: Lincomycine, CLI: Clindamycin PRI: Pristinamycine, QDA: Quinupristine - Dalfopristine, TET: Tetracycline, MIN: Minocycline, LVX: Levofloxacin, OFL: Ofloxacine, LNZ: Linezolid, FUC: fucidic Acid, FOS: Fosfomycine, FUR: Nitrofurantoïne, TSU: Cotrimoxazole, VAN: Vancomycine, TEC: Teicoplanine $\mathrm{ATB}=$ antibiotic $\mathrm{R}=$ resistant $\mathrm{S}=$ sensitive

Table 3. Protocol for the preparation of test samples.

\begin{tabular}{llllll}
\hline Tubes & T & $\mathbf{D}_{\mathbf{1}}$ & $\mathbf{D}_{\mathbf{2}}$ & $\mathbf{D}_{\mathbf{3}}$ & $\mathbf{D}_{\mathbf{5}}$ \\
\hline NaCl 9\%o & $2 \mathrm{~mL}$ & $2 \mathrm{~mL}$ & $2 \mathrm{~mL}$ & $2 \mathrm{~mL}$ & $2 \mathrm{~mL}$ \\
Inoculum test & $1 \mathrm{~mL}$ & $1 \mathrm{~mL}$ & $1 \mathrm{~mL}$ & $1 \mathrm{~mL}$ & $1 \mathrm{~mL}$ \\
Extract & $0 \mathrm{~mL}$ & $2 \mathrm{~mL}$ & $1 \mathrm{~mL}$ & $0,5 \mathrm{~mL}$ & $0,25 \mathrm{~mL}$ \\
Mueller Hinton broth & $7 \mathrm{~mL}$ & $5 \mathrm{~mL}$ & $6 \mathrm{~mL}$ & $6,5 \mathrm{~mL}$ & $6,75 \mathrm{~mL}$ \\
\hline
\end{tabular}


Table 4. Results of the in vitro toxicity test of Strychnos johnsonii extract on a susceptible to methicillin Staphylococcus aureus stream.

\begin{tabular}{llll}
\hline Tubes & Concentration of extract $(\mathbf{g} / \mathbf{m L})$ & Results of inhibition $\mathbf{t}_{\mathbf{1}}=\mathbf{2 4}$ Hours & Results of inhibition $\mathbf{t}_{\mathbf{2}}=\mathbf{4 8} \mathbf{h o u r s}$ \\
\hline $\mathrm{T}$ & 0 & Uncountable colonies & Uncountable colonies \\
$\mathrm{D}_{1}$ & 0,08 & 0 colonies & 0 colonies \\
$\mathrm{D}_{2}$ & 0,04 & 0 colonies & 0 colonies \\
$\mathrm{D}_{3}$ & 0,02 & 86 colonies & 0 colonies \\
$\mathrm{D}_{4}$ & 0,01 & Uncountable colonies & Uncountable colonies \\
$\mathrm{D}_{5}$ & 0,005 & Uncountable colonies & Uncountable colonies \\
$\mathrm{D}_{6}$ & 0,0025 & Uncountable colonies & Uncountable colonies \\
\hline
\end{tabular}

\subsection{Preparation of the Test Inoculum}

Cultures of 24 hours from the strain of Staphylococcus aureus diluted in $5 \mathrm{ml}$ of saline water were used to prepare a suspension of $2 \mathrm{McF}$ according to the breakpoints of the French Society of Microbiology. This suspension was diluted to $1 / 10$ th to obtain a concentration of inoculum test for about $6 \times 10^{8}$ germs / mL [12].

\subsection{Testing}

In 6 tubes numbered from D1 to D5 and a control T tube, were introduced successively: $2 \mathrm{~mL}$ of saline solution $(9 \%$ $\mathrm{NaCl}$ ), $1 \mathrm{~mL}$ of the test inoculum, and with the exception of the control tube T, concentrations of extract of Strychnos johnsonii following a dilution of geometric progression of reason $1 / 2$ adjusted to $10 \mathrm{~mL}$ adding Mueller Hinton broth. Ten $\mu \mathrm{L}$ of each dilution were then inoculated on Mannitol salt agar and incubated at the time $\mathrm{t} 0=0$ hours, $\mathrm{t} 1=24$ hours and $\mathrm{t} 2=48$ hours, at $37^{\circ} \mathrm{C}$, at the rate of two plates per dilution [13].

\subsection{Determination of MIC and MBC}

The MIC (Minimum Inhibitory Concentration) components are defined as the smallest concentration of extract for which no growth is visible to the naked eye. In this study, the growth was not clearly visible because of the opacity of the extract, the MIC was then been defined as the meeting point of intersection of the bacterial inhibition curve with the $\mathrm{x}$-axis within a period of 24 hours [14]; and the MBC (Minimum Bactericide Concentration), the smallest concentration of extract for which no bacterial growth was observed on Mannitol Salt agar [13]. The count was conducted by the «Standard Plate Count» technique using the following formula:

$\mathrm{N}=\Sigma \mathrm{C} / \mathrm{V}\left(\mathrm{n}_{1}+0,1 \mathrm{n}_{2}\right) \mathrm{d}$

$\mathrm{N}$ : number of colonies

$\mathrm{C}$ : sum of colonies counted on all selected plates of two successive dilutions and which contains at least 15 settlements and not more than 150 colonies.

$\mathrm{V}$ : volume of the inoculum applied to each plate, in $\mathrm{ml}$; $\mathrm{n}_{1}$ : number of plates selected at the first dilution;

$\mathrm{n}_{2}$ : number of plates selected at the second dilution;

$\mathrm{d}$ : dilution rate corresponding to the first chosen dilution.

\section{Results}

\subsection{Sterility Control of the Extract}

No bacterial growth were observed on Mannitol Salt, EMB and Sabouraud-Chloramphenicol agar plates after 48 hours of incubation, evidence that the extract contained no germs before the test.

\subsection{Determination of $M I C$ and $M B C$}

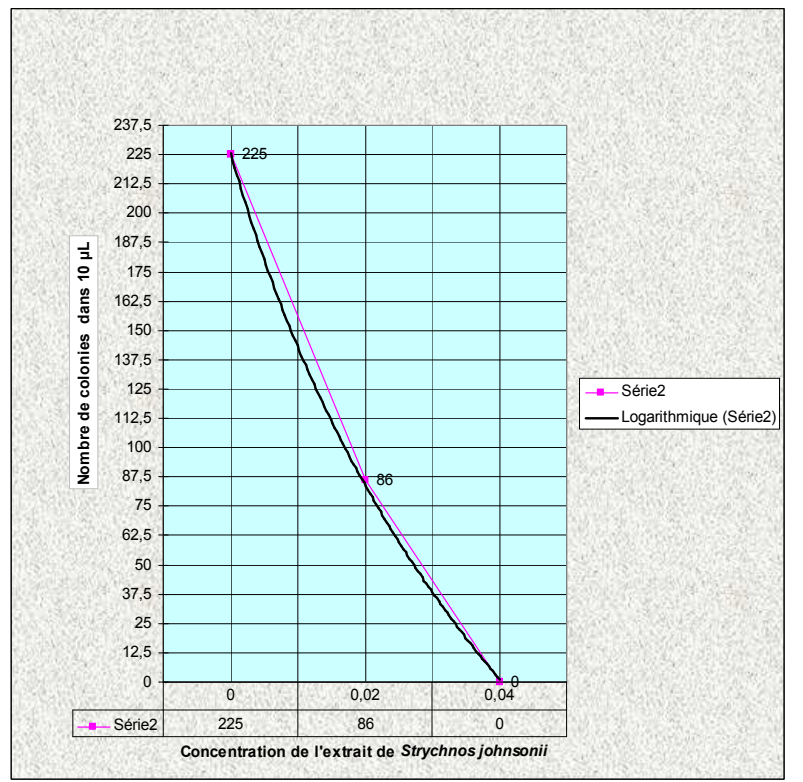

Figure 1. Inhibition curve of Staphylococcus aureus according to Strychnos johnsonii extract concentration 
The number of initial colonies for the time t0 averaged 225. Table 4 presents the results of the in vitro toxicity test of the extract from the bark of Strychnos johnsonii on Staphylococcus aureus. The point of intersection between the inhibition curve and the $\mathrm{x}$-axis as the MIC corresponds to $0,04 \mathrm{~g} / \mathrm{mL}$ (Figure 1). The smallest concentration of the extract for which the growth of Staphylococcus aureus is zero on the Mannitol salt agar was $0.04 \mathrm{~g} / \mathrm{mL}$. Therefore, the MIC amounts to MBC.

\section{Discussion}

The extract from the bark of Strychnos johnsonii stem is active on Staphylococcus aureus in vitro. The method used for the determination of the MIC due to an inability to appreciate the absence or the presence of the cloudiness in the tubes, has already been applied for the determination of MIC and MBC of some antibiotics in milk solutions, on bacteria isolated from bovine mastitis [14]. Regardless of the time of exposure of the bacteria to the extract, bacterial growth increases from $0.01 \mathrm{~g} / \mathrm{mL}$ concentration of the extract is no longer possible from $0.04 \mathrm{~g} / \mathrm{mL}$. It decreases at a concentration of $0.02 \mathrm{~g} / \mathrm{mL}$ and vanish over time.

The MBC/MIC equal to 1 report characterized a bactericidal power [15]. This bactericidal effect seems to depend on the concentration and the time of exposure of the bacteria to extract. It can be attributed to the presence of indole alkaloids. Indeed, some indole alkaloids of the Loganiaceae family are active in bacteria, the example of the Dihydocorynantheol and the active Tetrahydoalstonine on the Gram + and already isolated bark of stem of Strychnos johnsonii [16-19].

Unlike twigs, the extract from the bark of Strychnos johnsonii stem is active on Staphylococcus aureus [17]. Indeed, some indole alkaloids of the Loganiaceae family are active in bacteria. Their antibacterial action is not conferred to their cycles itself, but rather to oxygen-containing groups $(-\mathrm{OH}, \mathrm{R}-\mathrm{OH},-\mathrm{COOCH} 3,-\mathrm{OCH} 3)$ present on these cycles [17].

\section{Conclusion}

This study was to test the in vitro toxicity of an extract from Cameroonian Strychnos johnsonii on a strain of Staphylococcus aureus in order to justify its use as febrifuge plant. The results obtained showed a bactericidal effect, which could be, attributed to the presence of indole alkaloids in the plant.

\section{Ethical Considerations}

We obtained the authorisation of the Ethics Committee of the General Hospital of Douala.

\section{References}

[1] World Health Organization. (2002). Stratégie de l'OMS pour la médecine traditionnelle pour 2002-2005.

[2] Gurib-Fakim, A. (2006). Medicinal plants: traditions of yesterday and drugs of tomorrow. Molecular aspects of Medicine, 27(1), 1-93.

[3] Sapi, J. "G. Massiot in The Alkaloids: Chemistry and Pharmacology Vol. 47." (1995): 173-226.

[4] Tchinda, A. T., Ngono, A. R., Tamze, V., Jonville, M. C., Cao, M., Angenot, L., \& Frédérich, M. (2012). Antiplasmodial alkaloids from the stem bark of Strychnos malacoclados. Planta medica, 78(4), 377-382.

[5] Cao, R., Peng, W., Wang, Z., \& Xu, A. (2007). $\beta$-Carboline alkaloids: biochemical and pharmacological functions. Current medicinal chemistry, 14(4), 479-500.

[6] Rajesh P, Rajesh Kannan V, Latha S, Selvamani P. Phytochemical and Pharmacological Profile of Plants belonging to Strychnos Genus. Bioactive Phytochemicals: Perspectives for Modern Medicine. 2014; 1:275 - 321.

[7] Philippe, G., Angenot, L., De Mol, P., Goffin, E., Hayette, M. P., Tits, M., \& Frédérich, M. (2005). In vitro screening of some Strychnos species for antiplasmodial activity. Journal of ethnopharmacology, 97(3), 535-539.

[8] Leeuwenberg AJM. Flore du Cameroun. Museum National d'histoire naturelle. 1972; 16(12): 90, 140.

[9] Bisset, N. G. (1970). The African species of Strychnos, Part I. The ethno botany. Lloydia, 33, 201-43.

[10] Denoël A, Jaminet F, Detilleux G, Van Sumsen M, Merveille L. Contribution à l'étude phytochimique des Strychnos du Congo Belge. Ministère des colonies, Direction de l'agriculture, Bruxelles: Imifi; 1953. 208p

[11] Sandberg, F., Lunell, E., \& Ryrberg, K. J. (1969). Pharmacological and phytochemical investigations of African Strychnos species. Acta Pharmaceutica Suecica, 6(1), 79-102.

[12] Comité de l'Antibiogramme de la Société Française de Microbiologie. Recommandations [en ligne]. 2014 [consulted on $30^{\text {th }}$ may 2014]. Disponible: http ://www.Sfmmicrobiologie.org, CASFM_EUCAST_V1_0_2014.pdf.

[13] Larcher C, détermination de la sensibilité aux antibiotiques, détermination de la CMI. [On line]. 2008 [consulted on $15^{\text {th }}$ February 2014]. http://christelle.larcher.free.fr/IMG/pdf/determination_CMItr.pdf

[14] GANIERE, J. P., Mangion, C., \& Péridy, M. (2004). Détermination des Concentrations Minimales Inhibitrices ET Bactéricides de la cefquinome, la marbofloxacine, la tylosine et la spiramycine en solution dans du lait vis-à-vis de bactéries isolées de mammites bovines. Revue de médecine vétérinaire, 155(8-9), 411-416.

[15] Talbert M, Willoquet G, Gervais R. Le guide de Pharmacoclinique [en line]. Reuil-Malmaison: Wolters Kluwer France; 2009. [Consulted on $20^{\text {th }}$ April 2014]. 
[16] Verpoorte R, Kodde EW, Doorne H Van, Baerheim Svendsen A. Antimicrobial active Alkaloids from Strychnos afzelii. Planta medica 1978; 33:237-242

[17] Verpoorte, R., Van Beek, T. A., Thomassen, P. H. A. M., Aandewiel, J., \& Svendsen, A. B. (1983). Screening of antimicrobial activity of some plants belonging to the Apocynaceae
Journal of ethnopharmacology, 8(3), 287-302.

[18] Massiot G, Thepenier P, Jacquier MJ, Men-Olivier LL, Verpoorte R, Delaude C. Alkaloids of Strychnos johnsonii. Phytochemistry 1987; 26(10): 2839-2846.

[19] Buckingham J, Baggaley KH, Roberts Andrew D, Szabo LF. Dictionary of Alkaloids. Second edition. 2009. 2374p. 